\title{
Bringing the citizens closer to Europe: a mission for the media?
}

\author{
Carol Coulter
}

Published online: 22 March 2013

(C) ERA 2013

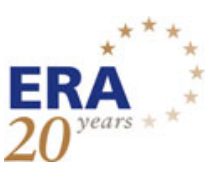

\begin{abstract}
This article deals with the role of the media with regard to the relationship between citizens and the European Union. Depending on the form and ownership of media organisations their priorities differ. The attitudes of the media towards the EU reflect not only the priorities of the owners but depend also of the stance of their customers. Media support of and hostility to the EU are both embedded in social and political reality. The problem lies with the lack of engagement of European citizens with their political parties and institutions. Politicians must listen to citizens' concerns and look for ways to involve them. The realities on the ground cannot be changed by the media. Independent media can have no mission to bring citizens closer to the EU, but can and should discuss the realities in a serious way.
\end{abstract}

Keywords EU $\cdot$ Media $\cdot$ Citizens

The title wisely includes a question mark. A very quick answer to the question would be "No", bringing to an end the discussion.

We cannot have a discussion on this title without asking what we mean by the media, what we mean by Europe and what we mean by citizens.

First of all, the media is, and must be, independent of both state and EU institutions, something which has been repeatedly stated by the EU's own institutions. It's Task Force on Freedom and Pluralism in the Media, "Freedom and pluralism of the media, including independent media governance, are key elements for enabling the

The article is based on the speech delivered by the author at the congress The citizen at the heart of EU law, organised by ERA to commemorate the $20^{\text {th }}$ anniversary of its foundation on 18-20 October 2012 in Trier.

C. Coulter

c/o Academy of European Law, Metzer Allee 4, 54295 Trier, Germany 
exercise of freedom of expression, which constitutes one of the essential foundations of the European Union."1

How, then, can it be a "mission" for the media to bring the citizens closer to Europe, that is, the institutions of the EU, both now and as they develop into the future? Or, indeed, to have a mission to perform the reverse: bring the EU closer to the citizens? If the media is to be independent, it must be independent not only of governments, but of EU institutions. It has no "mission", and can have no mission, to bring citizens closer to them.

Despite this, it is often the case that various institutions, NGOs and lobby groups feel the media has a "mission" or a "responsibility" to present their analysis, information and views to the public. This is accompanied by a perception of the media as a homogeneous entity. Nothing could be further from the truth.

It is stating the obvious, but it needs to be stated: the media is heterogeneous in form, in ownership, in outlook, in its links with political parties and commercial entities. It consists of many forms: print, broadcasting and, most recently, social media. These in turn are variously owned, ranging from publicly-owned media, primarily in the broadcast area, and includes those, like The Irish Times in Ireland and the Guardian in the UK, which are owned by co-operatives or trusts, and those media, the majority, which are owned by big private corporations. They all have their own priorities and agendas.

Public service broadcasting, for example, is governed by rules that include a responsibility to inform the public and be impartial. The Articles of Association of media trusts are likely to contain clauses specifying their role in public education and the promotion of civic responsibility, albeit in vague terms.

Media organisations that are privately owned will operate according to the media law of the country in which they publish or broadcast, but their primary responsibility will be to ensure a continuing return for their shareholders. Some of them may be linked to political parties and political viewpoints in countries where they operate; others are not directly linked, but tend to align with a defined readership or audience. Inevitably this will be reflected in the way in which they cover news and comment on current events, including European affairs.

Among the English language media, for example, particularly the print media, there is widespread hostility to the EU and its institutions, mainly in the UK. This reflects both the attitudes of the main media conglomerates which own some of the main newspapers, and those of the electorate of the governing party, the Conservatives. This approach is not capricious or accidental; it is embedded in social and political reality.

In Ireland the media is broadly supportive of the EU. This again reflects the fact that until very recently there was widespread support for the EU among the Irish electorate and all the main political parties. Even now, three years after the advent of the Troika and the austerity measures that came with the bailout, there is much frustration about the failure of the EU to solve the problems of the euro, but little overt hostility to the EU itself. All of this is reflected in the media.

\footnotetext{
${ }^{1}$ EU Task Force on Co-ordination of Media Affairs: Freedom and Pluralism of the Media, http:// ec.europa.eu/information_society/media_taskforce/pluralism/index_en.htm (19/11/2012).
} 
In general, therefore, the media in any given country reflects, more or less, the balance of forces within the political institutions and among the political parties. It does not exist outside them, though the ownership of large tranches of the media by powerful individuals or groups can and does distort the political discourse in their favour, or in favour of those they support.

That has a damaging effect on democracy, and it is arguable that the EU should consider robust measures to ensure pluralism and true independence, not only of governments, but of powerful individuals and corporations, for the media. But that is a discussion for another day.

Meanwhile, we cannot consider the role of the media in Europe without considering the political context in which the media operate, and in particular the relationship of EU citizens with their various democracies and their political parties. There is a crisis in European democracy, in that political parties and institutions are increasingly alienated from, and operate independently of, their populations. This has been extensively analysed by the late Irish political scientist, Peter Mair, who died last year, before he could extend his analysis to the impact of the current crisis.

In this jubilee congress this phenomenon, as it applies to the EU and its institutions, has been outlined extensively by Jo Shaw in a paper provided to the congress. Referring specifically to Greece, she writes; "Greece has seen polarisation and widespread demands for a new political order as its continuing membership of the Eurozone and even of the EU itself has continued to be called into question ..."2 accompanied by increased votes for parties of the far right and the left. She points out that in many member states the rise of the far right has led to an increase in hostility towards immigrants, calling into question EU-sponsored efforts to promote integration and tolerance.

This absence of engagement with the established political parties is not limited to countries like Greece who are in the throes of financial crisis. In the UK the recent Conservative party conference was described as follows in the Sunday Times newspaper:

The Conservatives aren't here, however, because the tickets cost hundreds of pounds, far more than anyone would spend if they didn't have an axe to grind or a grinder to sell. Lots of MPs don't bother coming.

In place of Conservatives there are hundreds and hundreds of men in appallingly skimpy suits with pointy shoes and careless greased hair, carrying satchels... They are the nebulous new class of PRs and special pleaders for greenfield building, nuclear power, bypasses and runways, broadband and delicensing. They are think tank wonks and paid-interest researchers.

Young sallow men who can't explain what they do in less than three paragraphs. They aren't exactly political - they don't do politics, they do policy.... mostly they are a new life form: opportunists, scrollers. They form a thick crust between the electorate and the elected....

Party membership has collapsed, some whisper by as much as 90 per cent since the war [a Europe-wide phenomenon analysed by Mair]. It's not just the

${ }^{2}$ Shaw [2], p. 2 f. 
Tories-Labour is vanishing and both Libs and Dems are being rubbed out too. Not so much popular movements as political sects, financed privately as specialist timeshare power corporations. ${ }^{3}$

Undoubtedly this description could be replicated from party conferences all over Europe. Yet these are the parties who campaign for seats in the national and European parliaments, who take public office on the basis of, among other things, their strategy in Europe, who form governments which take the decisions at European level we are now all living with.

If the citizens of Europe cannot be engaged with their political parties, how can they be engaged with the institutions they run? All the more so when these institutions are far away, not rooted in history and tradition and appear to be dominated by outof-touch bureaucracies?

The architects of the EU did not see it this way, and there are many arguments that this is a misrepresentation of what the EU does and what it stands for. We have heard over the weekend of the various ways in which the citizens of Europe have been able to assert their rights using EU law.

But the overwhelming experience of the EU for those citizens who live in countries like Greece, Ireland, Portugal and Spain is one of austerity, including very severe hardship. This is a reality that affects many tens of millions of EU citizens. Many of the issues where citizens of the Union have invoked their rights under EU law have involved relatively small numbers of people.

This raises another question: what do we mean by EU citizen? Leaving aside for the moment the discussion we have had about the nature of EU citizenship, it is clear that the citizens of Europe are not homogeneous, even apart from the obvious differences of language, culture and nationality. Within each member state there are profound differences of social class and in many states there are multiple ethnic groups.

Many people in these countries rarely exercise their rights as EU citizens, or do not think they do. As Jo Shaw points out, the right of free movement is only a benefit to those who move. It is often not perceived as at all positive by those who do not wish to move and into whose towns and cities people come from other EU states.

The Zambrano case, ${ }^{4}$ for example, will have been perceived very differently by the immigrant parents of EU born children and the NGOs supporting the rights of immigrants on the one hand, and those tempted by parties of the far right on the other.

The media cannot change these realities. What it can do is discuss them. Such a discussion should be in a serious, factually accurate way. It is deplorable that this is often not the case. Some sections of the media stereotype certain groups, distort what happens both at a national and EU level, shamelessly campaign on the basis of untruths. That is the price we pay for an independent media, though there are questions to be asked about ownership and control, as I said earlier.

The fundamental problem, however, lies not with our media but with our political institutions and our political parties. They must re-engage with people's experience in

\footnotetext{
${ }^{3}$ Gill [1].

${ }^{4}$ C-34/09, Ruiz Zambrano, Judgment of the Court of 8.3.2011.
} 
a direct way, listen to their concerns and attempt to address them. These concrete concerns cannot be divorced from the issue of the nature of European citizenship and the thrust of the EU towards greater integration. The questions people will ask will not primarily concern the abstract one of the balance between state and EU sovereignty, but what this means for social solidarity, for reducing unemployment, for public services...

Such an engagement by politicians may entail moving outside their comfort zone, moving away from life among a professional caste of politicians and looking for ways to involve citizens in decisions that affect them. The citizens' initiatives could have a role here, but a limited one and they will not be a panacea.

However, this is now becoming urgent. What is happening in Greece is not pretty.

I happened to be there last month. The depredation of the social structure of a whole society was obvious, as was the determination of the Greeks to survive it. But what was chilling was the groups of young and not-so-young men patrolling certain streets in black T-shirts emblazoned with the insignia of Golden Dawn, watched indifferently_-perhaps even approvingly_by the police. It can only be imagined what such a sight feels like to immigrants in Greece.

This is the spectre that is haunting Europe, and confronting it is a task for Europe's politicians. When they do so in a meaningful way I have no doubt much of the media will applaud them.

\section{References}

1. Gill, A.A.: A nasty case of blue murder. Sunday Times (14 October 2012)

2. Shaw, J.: EU citizenship and the edges of Europe. CITSE Working Paper 19 (2012). http://www.law. ed.ac.uk/file_download/series/372_eucitizenshipandtheedgesofeurope.pdf (19/11/2012) 